Egyptian Journal of Aquatic Biology \& Fisheries Zoology Department, Faculty of Science,

Ain Shams University, Cairo, Egypt.

ISSN $1110-6131$

Vol. 25(2): 21 - 35 (2021)

www.ejabf.journals.ekb.eg

\title{
Population Genetics of Fast- and Slow-Growing Strains of Clarias gariepinus (Osteichthyes: Clariidae) as Revealed by Microsatellite Markers
}

\author{
Folasade A. Ola-Oladimeji \\ Department of Zoology and Environmental Biology, Faculty of Science, Ekiti State University, Ado \\ Ekiti. P.M.B. 5363, Ekiti State, Nigeria. \\ folasade.majolagbe@eksu.edu.ng
}

\section{ARTICLE INFO}

Article History:

Received: Nov. 16, 2020

Accepted: Dec. 18, 2020

Online: March 12, 2021

Keywords:

Clarias gariepinus;

Microsatellite;

variability;

growth;

locus

\section{ABSTRACT}

This study employed microsatellite DNA markers on cultured fast- and slowgrowing strains of an important freshwater catfish, Clarias gariepinus from four populations in Southwestern Nigeria with a view to providing information on their genetic variability in relation to growth performance. Genomic DNA was extracted from the blood of each individual fish from the selected groups following standard procedures. The DNA sample collected was then amplified in a thermocycler using Cga01, Cga02, Cga03, Cga05, Cga06, Cga09 and Cga10 markers. The amplicons generated were subjected to genotyping and the corresponding alleles scored. The higher fixation index values identified in the slow-growing strains of adult $C$. gariepinus indicated the existence of small number of heterozygote genotypes and an excess of homozygote genotypes compared to the fast-growing strains of adult C. gariepinus, suggesting that heterozygosity confers better growth performance. The $C$. gariepinus fast-growing strains also had higher genetic variability than the slow-growing populations. The $\mathrm{Cga} 02$ locus was identified as the specific locus on which significance levels were consistently expressed. Thus, it may be a potential locus for breeding studies of $C$. gariepinus. Analysis by Chi-square tests across all loci and populations revealed that not all the seven loci conformed to HardyWeinberg equilibrium in each population.

\section{INTRODUCTION}

Among other fish in Nigeria, Clarias gariepinus is mostly reared because of its good properties and these have encouraged farmers to invest in its seed production. However, most C. gariepinus farmers use brood-stock of unknown genetic quality and this practice has led to inbreeding resulting in the production of unviable hybrids which subsequently cause low productivity in fish farms. Research to increase the yield of C. gariepinus focused mainly on the food and feeding habits (Adewumi and Ola-Oladimeji, 2016; Onura et al., 2018), embryology (Olaniyi and Omitogun, 2014), hybridization (Awodiran et al., 2000; Olaleye, 2005), cytogenetics (Aluko and Awopetu, 1995; Awodiran et al., 2000; Majolagbe et al., 2011) and genetic variability (Popoola $\boldsymbol{e t}$ al., 2014). Other genetic techniques that are being used for the improvement of aquaculture fishes are sex reversal, ploidy manipulations, androgenesis and gynogenesis (Dunham, 2011; Olaniyi and Omitogun, 2012). 
Variation is genetically determined (Ikpeme $\boldsymbol{e t}$ al., 2015). Hence, a wide variety of markers have since been developed for different aquaculture species. One commonly used method to study the genetics of populations is the use of microsatellite DNA markers.

Microsatellite DNA are short DNA sequences that exist in multiple copies repeated in tandem (Pierce, 2012). Microsatellites, also known as Simple Sequence Repeats (SSRs) or Short Tandem Repeats (SRTs) are composed of tandem repeats of two to six nucleotides that are dispersed across the genomes, both in coding and non-coding regions. Dinucleotide repeats are the most common and they are found in most species compared to other nucleotide repeats (mono, tri, etc.) (Li et al., 2002). Most microsatellite loci are more or less small, ranging from few to a few hundred repeats and microsatellites containing a larger number of repeats are more polymorphic, though polymorphism has been observed in microsatellites with as few as five repeats (Karsi et al., 2002).

Microsatellite markers have become a marker of choice in many genetic studies. Therefore, this study aims to characterize the fast- and slow-growing strains of $C$. gariepinus genetically using microsatellite markers and provide information on their genetic variability.

\section{MATERIALS AND METHODS}

\section{Collection and identification of fish specimens}

Eight-week old fast- and slow-growing strains of $C$. gariepinus produced by specially managed brood-stocks were identified and collected from four selected farms. Samples were collected from the following selected locations; the Teaching and Research Farm, Federal University of Agriculture, Abeokuta, Ogun State, (FUNAAB) ( $\left.7^{\circ} 09^{\prime} 20^{\prime \prime} \mathrm{N}, 3^{\circ} 20^{\prime} 42^{\prime \prime} \mathrm{E}\right)$;

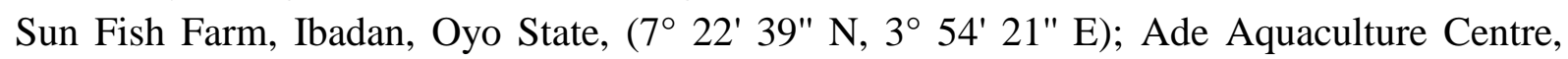
Ado-Ekiti, Ekiti State, (7 37' 23" N, $5^{\circ} 13^{\prime} 15^{\prime \prime}$ E); and Edens Fish Farm, Ile-Ife, Osun State, ( $7^{\circ} 28^{\prime} 0^{\prime \prime} \mathrm{N}$ and $\left.4^{\circ} 34^{\prime} 0^{\prime \prime} \mathrm{E}\right)$ in Southwestern Nigeria (Fig. 1). At the sampling sites, each of the 40 fast- and 40 slow-growing strains was separated appropriately and the fish were raised in different tanks simultaneously at Edens Fish Farm, Ile-Ife for 16 weeks.

\section{Experimental setup}

Clarias gariepinus juveniles in each tank were fed with commercial floating feed, containing $45 \%$ crude protein two times daily (7.30 a.m. and 6.30 p.m.). During the culture period, the water temperature was taken with a thermometer weekly while $\mathrm{pH}$ and nitrite were also measured weekly using Colombo Aquatest ${ }^{\circledR}, 2011$ water testing kit to ensure that the environment was within tolerant limits expected for the $C$. gariepinus populations.

\section{Evaluation of growth performance}

At the end of the 16-week culture period for 320 fast- and slow-growers of $C$. gariepinus, five largest fast-growing $C$. gariepinus from each experimental grouping were sorted and coded accordingly as follows; FAB 1-5= Fast-growers Abeokuta 1-5, FIB 1-5= Fast-growers 

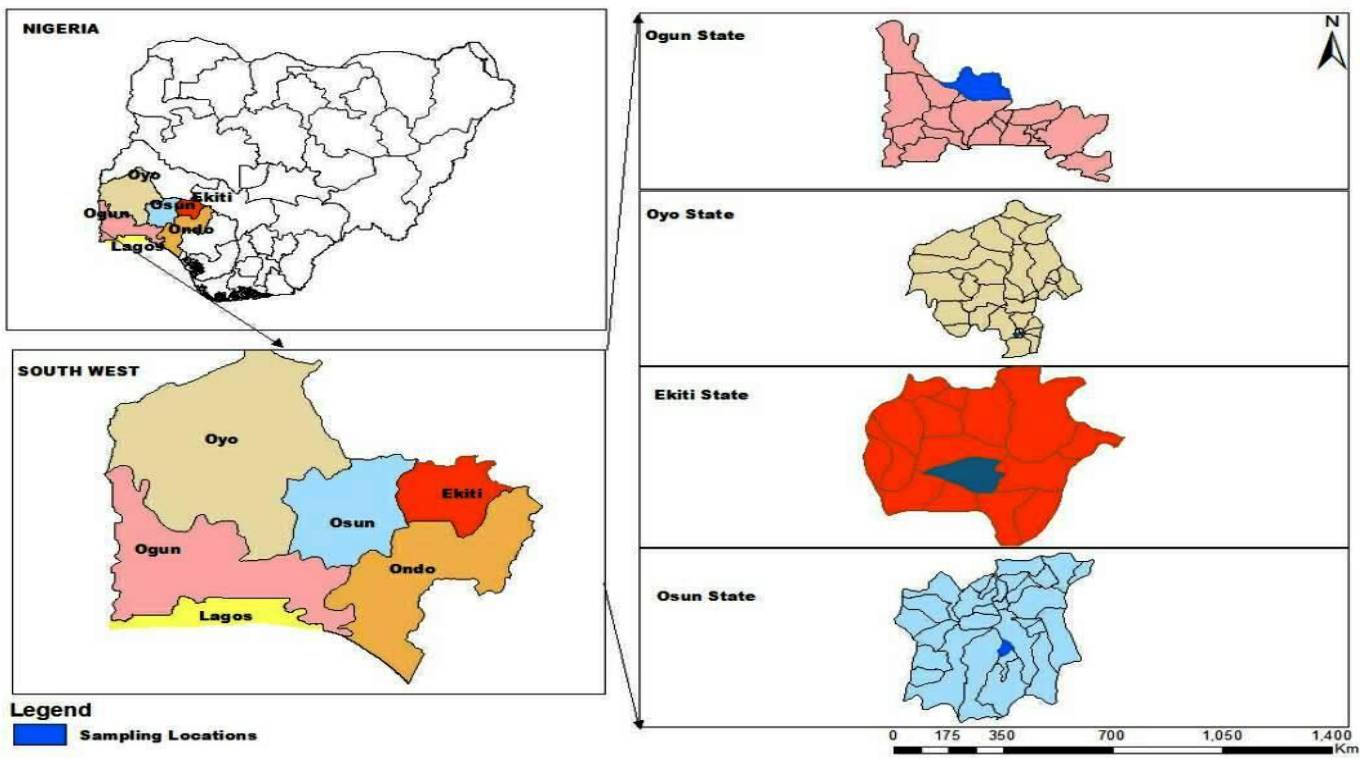

Fig. 1. Map of Nigeria with colour-coded states where the experimental C. gariepinus juveniles were collected (Ola-Oladimeji et al., 2020)

Ibadan 1-5, FAD 1-5= Fast-growers Ado-Ekiti 1-5, FIL 1-5= Fast-growers Ile-Ife 1-5. The five smallest slow-growers were also labelled as follows; SAB 1-5= Slow-growers Abeokuta 1-5, SIB 1-5= Slow-growers Ibadan 1-5, SAD 1-5= Slow-growers Ado-Ekiti 1-5 and SIL 15= Slow-growers Ile-Ife 1-5.

Growth performance of these strains was done by measuring their total length (TL) and body weight (BW) with a measuring board and digital electronic scale (TH-1000, PEC Medical USA) respectively.

\section{Blood sample collection for DNA extraction}

Genomic DNA was then extracted from the blood of each of the individual fish from the selected groups using NORGEN Blood Genomic DNA Isolation Kit (NORGEN, Biotechnology Corporation, Canada, 2014). The extraction was performed according to ElMogy et al. (2016), using spin column chromatography method.

\section{Microsatellite PCR and electrophoresis}

DNA amplification was done using microsatellite primers (Cga01, Cga02, Cga03, Cga05, Cga06, Cga09 and Cga10), according to standard but modified methods of Galbusera et al. (1996). The characteristics of the microsatellite primers were utilized in Table 1.

The amplified products $(8 \mu \mathrm{l})$ of each sample were separated by electrophoresis in $1 \%$ agarose gels buffered with $1 \mathrm{X}$ TAE and the polymorphisms among the amplification products were detected by staining with $15 \mu$ Ethidium Bromide. A PCR Sizer 100 bp DNA ladder (100bp - 1,000bp) (Norgen Biotek Corporation, Canada) was electrophoresed alongside the microsatellite reactions respectively as molecular weight marker. Electrophoresis was run at $100 \mathrm{~V}$ for $2.5 \mathrm{~h}$. Finally, the DNA bands were examined under Ultra-Violet (UV) transilluminator system (ZENITH, India), and the stained gels were photographed and saved 
Table 1. Characterization of seven microsatellite primer sets (Galbusera et al., 1996) used in the analysis, including the repeat array, primer sequences and annealing temperatures $\left(\mathrm{Ta}\left({ }^{\circ} \mathrm{C}\right)\right)$

\begin{tabular}{|c|c|c|c|}
\hline Primers & Repeat array & Primer Sequences $\left(5^{\prime} \rightarrow 3^{\prime}\right)$ & $\mathbf{a}\left({ }^{\circ} \mathbf{C}\right)$ \\
\hline Cga01 & $(\mathrm{GT})_{15}$ & $\begin{array}{l}\text { F: GGCTAAAAGAACCCTGTCTG } \\
\text { R: TACAGCGTCGATAAGCCAGG }\end{array}$ & 55.0 \\
\hline $\mathrm{Cga02}$ & $(\mathrm{GT})_{10} \mathrm{~N}_{2}(\mathrm{GT})_{8}$ & $\begin{array}{l}\text { F: GCTAGTGTGTGAACGCAAGGC } \\
\text { R: ACCTCTGAGATAAAACACAGC }\end{array}$ & 54.6 \\
\hline $\mathrm{Cga03}$ & $(\mathrm{GT})_{21}$ & $\begin{array}{l}\text { F: CACTTCTTACATTTGTGCCC } \\
\text { R: ACCTGTATTGATTTCTTGCC }\end{array}$ & 51.1 \\
\hline $\mathrm{Cga05}$ & $(\mathrm{GT})_{11} \mathrm{~N}_{2}(\mathrm{GT})_{2}$ & $\begin{array}{l}\text { F: TCCACATTAAGGACAACCACCG } \\
\text { R: TTTGCAGTTCACGACTGCCG }\end{array}$ & 57.9 \\
\hline $\mathrm{Cga06}$ & $(\mathrm{GT})_{5} \mathrm{~N}_{2}(\mathrm{GT})_{9}$ & $\begin{array}{l}\text { F: CAGCTCGTGTTTAATTTGGC } \\
\text { R: TTGTACGAGAACCGTGCCAGG }\end{array}$ & 56.0 \\
\hline Cga09 & $\begin{array}{l}(\mathrm{GA})_{3} \mathrm{~N}_{3}(\mathrm{GT})_{11} \mathrm{~N} \\
(\mathrm{GT})_{6} \mathrm{~N}_{2}(\mathrm{GT})_{4}\end{array}$ & $\begin{array}{l}\text { F: CGTCCACTTCCCCTAGAGCG } \\
\text { R: CCAGCTGCATTACCATACATGG }\end{array}$ & 57.8 \\
\hline Cga10 & $(\mathrm{GT})_{2} \mathrm{~N}_{2}(\mathrm{GT})_{15}$ & $\begin{array}{l}\text { F: GCTGTAGCAAAAATGCAGATGC } \\
\text { R: TCTCCAGAGATCTAGGCTGTCC }\end{array}$ & 56.4 \\
\hline
\end{tabular}

on the computer.

\section{Scoring of microsatellite bands}

Microsatellite bands were scored with ImageJ, image processing and analysis software (NIH image, 2017) and sizes were estimated by semi-log plot.

\section{Statistical analysis}

Descriptive statistics, Student's t-test, Analysis of variance (ANOVA), Duncan's multiple range test (DMRT) were done with Microsoft Office Excel (2007) and IBM SPSS Statistics (Version 22, 2013) software.

8. Data analyses for microsatellite DNA

Microsatellite allelic data were analysed using GenAlEx 6.502 genetic software (Peakall and Smouse, 2012) to produce genetic parameters. Values among groups were subjected to ANOVA and mean comparisons were made using DMRT where there were significant differences. Also, microsatellite genotype frequencies were tested for deviations from the Hardy-Weinberg equilibrium (HWE) with Chi-square test. Significance for statistical tests was taken at $\mathrm{p}<0.05$. 


\section{RESULTS}

\section{Growth performance-related traits of C. gariepinus}

Differences in total length and body weight between the fast- and slow-growing strains of $C$. gariepinus used for microsatellite DNA analysis are shown in Table 2. The total length was significantly lower at $\mathrm{p}<0.05$ in the slow-growers than in the fast-growing strains. Also, the difference in their body weights was statistically significantly different at $p<0.05$, with the fast-growers having the higher recorded value.

Table 2. Differences in length and weight between the two strains of $C$. gariepinus used for DNA analysis

\begin{tabular}{lll}
\hline Strains & Total length $(\mathbf{c m})$ & Body weight $(\mathbf{g})$ \\
\hline Fast-growing C. gariepinus & $40.44^{\mathrm{a}} \pm 0.58$ & $466.66^{\mathrm{a}} \pm 18.66$ \\
Slow-growing C. gariepinus & $21.55^{\mathrm{b}} \pm 0.50$ & $81.89^{\mathrm{b}} \pm 5.62$ \\
\hline
\end{tabular}

*Means in the same column superscripted by different letters differed significantly $(\mathrm{P}<0.05)$

\section{Microsatellite DNA Analysis}

The microsatellite DNA fingerprints (PLATE 1) were scored using the base pairs of the bands; homozygotes with single bands scored as a single base pair value repeated two times and heterozygotes with double bands as two different base pair values (Awodiran and Afolabi, 2018) with the aid of GenAlEx 6.502 genetic software (Peakall and Smouse, 2012).
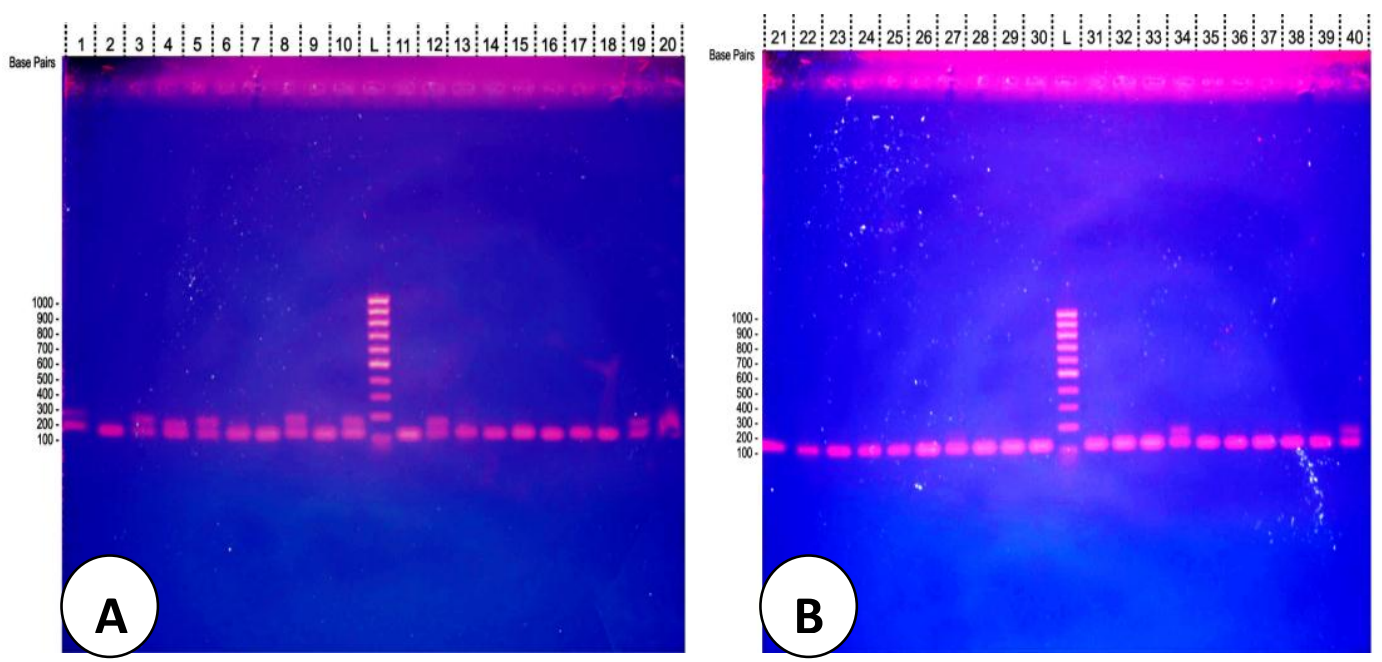

PLATE 1 (A and B). Agarose gel electrophoretic profile of microsatellite DNA for the Cga10 primer of adult $C$. gariepinus

Lanes 1-5= FAB (Abeokuta fast-growers), 6-10= SAB (Abeokuta slow-growers), L = DNA ladder, 11-15=FIB (Ibadan fast-growers), 16-20=SIB (Ibadan slow-growers). Lanes 21-25= FAD (Ado-Ekiti fast-growers) and 2630= SAD (Ado-Ekiti slow-growers), L = DNA ladder, lanes 31-35=FIL (Ile-Ife fast-growers) and 36-40=SIL (Ile-Ife slow-growers). 
The summary of homozygosity and heterozygosity obtained after scoring the bands across seven microsatellite loci in the fast-and slow-growing populations of $C$. gariepinus is shown in Table 3. Across all loci, the total percentage homozygosity (37.13\%) was higher in the slow-growers compared to the fast-growers with $35.66 \%$ homozygosity. However, the reverse trend was observed in the heterozygosity analysis with the fast-growers having higher heterozygosity $(14.34 \%)$ compared to $12.87 \%$ heterozygosity recorded for the slow-growing populations (Table 3).

Table 3. Summary of the homozygosity and heterozygosity obtained after scoring the bands in fast-and slow-growing C. gariepinus strains studied at seven microsatellite loci

\begin{tabular}{lllll}
\hline & \multicolumn{2}{c}{ Slow-growers } & \multicolumn{2}{c}{ Fast -growers } \\
\cline { 5 - 6 } Primer (Locus) & Homozygotes & Heterozygotes & Homozygotes & Heterozygotes \\
\cline { 3 - 5 } Cga01 & 16 & 4 & 14 & 5 \\
Cga02 & 18 & 1 & 14 & 6 \\
Cga03 & 10 & 9 & 10 & 8 \\
Cga05 & 18 & 2 & 19 & 1 \\
Cga06 & 11 & 8 & 14 & 5 \\
Cga09 & 13 & 6 & 12 & 8 \\
Cga10 & 15 & 5 & 14 & 6 \\
\hline Total & 101 & 35 & 97 & 39 \\
Total $(\%)$ & 37.13 & 12.87 & 35.66 & 14.34 \\
\hline
\end{tabular}

Results in Table 4 showed genetic variability estimates for each growth group of adult C. gariepinus across the 7 microsatellite loci. Analyses showed that the number of alleles was significantly higher $(\mathrm{p}<0.05)$ in fast-growers collected from Abeokuta than in fast- and slowgrowers from Ado-Ekiti and Ile-Ife. However, the number of alleles recorded in fast-growers from Abeokuta was non-significantly different ( $p>0.05$ ) from fast-growing strain from Ibadan and slow-growing strains from Abeokuta and Ibadan respectively. The number of effective alleles in the fast-growing strain from Abeokuta was also found to be significantly higher $(\mathrm{p}<0.05)$ than all the other fast- and slow-growing strains of $C$. gariepinus.

The Shannon's information index (I) (Table 4) of the fast- and slow-growing strains from Ado-Ekiti and Ile-Ife and the slow-growing strain from Abeokuta was significantly lower $(p<0.05)$ than those of the fast-growing strain from Abeokuta. The Shannon's information index of the fast-growing strain was however, non-significantly different ( $p>0.05$ ) from those of the slow- and fast-growing strains collected from Ibadan.

The observed heterozygosity among the different populations were found to be nonsignificantly different $(p>0.05)$ from each other. However, the expected heterozygosity $(\mathbf{H e})$ was significantly higher $(\mathrm{p}<0.05)$ in the Abeokuta fast-growing strain when compared with those of slow- and fast-growing strains from Ado-Ekiti and Ile-Ife. The expected heterozygosity in the slow- and fast-growing strains collected from Abeokuta and Ibadan was however, found to be non-significantly different $(p>0.05)$ from each other. 
The fixation index (F) among the different populations was non-significantly different $(\mathrm{p}>0.05)$ from each other. Analysis however showed that the individual heterozygosity (Hindiv.) was significantly higher $(\mathrm{p}<0.05)$ in the Abeokuta fast-growing strain when compared with slow- and fast-growing strains from Ado-Ekiti. The individual heterozygosity values in the fast-growing Abeokuta, Ibadan and Ile-Ife strains and those of slow-growing strains from Abeokuta, Ibadan and Ile-Ife were not significantly different ( $p>0.05)$ from each other.

Table 4. Genetic variability estimates of each C. gariepinus population across the seven microsatellite loci. (Standard error in parentheses)

\begin{tabular}{llllllll}
\hline Population & Na & Ne & I & Ho & He & F & H-indiv. \\
Slow-growers & & & & & & & \\
SAB & $5.286^{\mathrm{ab}}$ & $4.475^{\mathrm{a}}$ & $1.530^{\mathrm{a}}$ & $0.314^{\mathrm{a}}$ & $0.754^{\mathrm{ab}}$ & $0.608^{\mathrm{a}}$ & $0.314^{\mathrm{ab}}$ \\
& $(0.680)$ & $(0.603)$ & $(0.128)$ & $(0.114)$ & $(0.029)$ & $(0.141)$ & $(0.07)$ \\
& & & & & & & \\
SIB & $5.714^{\mathrm{ab}}$ & $4.826^{\mathrm{a}}$ & $1.625^{\mathrm{ab}}$ & $0.336^{\mathrm{a}}$ & $0.778^{\mathrm{ab}}$ & $0.582^{\mathrm{a}}$ & $0.324^{\mathrm{ab}}$ \\
& $(0.565)$ & $(0.547)$ & $(0.103)$ & $(0.108)$ & $(0.023)$ & $(0.128)$ & $(0.053)$ \\
& & & & & & & \\
SAD & $4.143^{\mathrm{a}}$ & $3.514^{\mathrm{a}}$ & $1.328^{\mathrm{a}}$ & $0.114^{\mathrm{a}}$ & $0.711^{\mathrm{a}}$ & $0.834^{\mathrm{a}}$ & $0.124^{\mathrm{a}}$ \\
& $(0.143)$ & $(0.165)$ & $(0.030)$ & $(0.059)$ & $(0.014)$ & $(0.084)$ & $(0.061)$ \\
& & & & & & & \\
SIL & $4.857^{\mathrm{a}}$ & $3.927^{\mathrm{a}}$ & $1.416^{\mathrm{a}}$ & $0.264^{\mathrm{a}}$ & $0.717^{\mathrm{a}}$ & $0.640^{\mathrm{a}}$ & $0.262^{\mathrm{ab}}$ \\
& $(0.553)$ & $(0.595)$ & $(0.117)$ & $(0.056)$ & $(0.034)$ & $(0.059)$ & $(0.113)$
\end{tabular}

Fast-growers

FAB

$\begin{array}{lllllll}6.857^{\mathrm{b}} & 6.270^{\mathrm{b}} & 1.847^{\mathrm{b}} & 0.400^{\mathrm{a}} & 0.829^{\mathrm{b}} & 0.536^{\mathrm{a}} & 0.400^{\mathrm{b}} \\ (0.705) & (0.616) & (0.112) & (0.123) & (0.021) & (0.142) & (0.07)\end{array}$

FIB

$\begin{array}{lllllll}5.429^{\mathrm{ab}} & 4.500^{\mathrm{a}} & 1.545^{\mathrm{ab}} & 0.321^{\mathrm{a}} & 0.754^{\mathrm{ab}} & 0.593^{\mathrm{a}} & 0.314^{\mathrm{ab}}\end{array}$

$\begin{array}{lllllll}(0.685) & (0.570) & (0.133) & (0.095) & (0.032) & (0.112) & (0.083)\end{array}$

FAD

$\begin{array}{lllllll}4.714^{\mathrm{a}} & 4.032^{\mathrm{a}} & 1.453^{\mathrm{a}} & 0.150^{\mathrm{a}} & 0.743^{\mathrm{a}} & 0.793^{\mathrm{a}} & 0.148^{\mathrm{a}} \\ (0.286) & (0.337) & (0.063) & (0.059) & (0.019) & (0.084) & (0.045)\end{array}$

FIL

$$
\begin{array}{lllllll}
5.000^{\mathrm{a}} & 4.149^{\mathrm{a}} & 1.489^{\mathrm{a}} & 0.279^{\mathrm{a}} & 0.747^{\mathrm{a}} & 0.634^{\mathrm{a}} & 0.281^{\mathrm{ab}}
\end{array}
$$

$\begin{array}{lllllll}(0.436) & (0.357) & (0.089) & (0.077) & (0.024) & (0.102) & (0.092)\end{array}$

*Means in the same column superscripted by different letters were significantly different $(\mathrm{P}<0.05)$ $\mathrm{SAB}=$ Slow-growers Abeokuta, SIB $=$ Slow-growers Ibadan, SAD = Slow-growers Ado-Ekiti, SIL= Slowgrowers Ile-Ife, FAB=Fast-growers Abeokuta, FIB= Fast-growers Ibadan, FAD= Fast-growers Ado-Ekiti, FIL= Fast-growers Ile-Ife, $\mathrm{Na}=$ Number of alleles, $\mathrm{Ne}=$ Number of effective alleles, $\mathrm{I}=$ Shannon's information index, $\mathrm{Ho}=$ Mean observed heterozygosity, $\mathrm{He}=$ Mean expected heterozygosity, $\mathrm{F}=$ Fixation index, $\mathrm{H}$-indiv.= Individual heterozygosity. 
The genetic variability estimates between the fast- and slow-growing strains of adult C. gariepinus when microsatellite allelic data based on each microsatellite locus were used for analyses in Table 5.

Fast-growing strains had higher number of alleles (Na) at all loci except at $\mathrm{Cga03}$ and Cga06. Further analyses however showed that the recorded differences were only significantly higher $(\mathrm{p}<0.05)$ at $\mathrm{Cga02}$ locus. Except at locus $\mathrm{Cga} 03$, the number of effective alleles $\mathbf{( N e )}$ in the fast-growing strains was higher than those of the slow-growers at all the other loci examined. In addition, the number of effective alleles was recorded to be significantly higher $(\mathrm{p}<0.05)$ in the fast-growers only at locus Cga02. The Shannon's information index (I) values were higher in the fast-growing strains of the fish than in the slow-growing strains. The exception occurred only at Cga03 locus where the slow-growers had higher Shannon's information index values. The higher I values recorded in the fastgrowers was however only significantly higher $(\mathrm{p}<0.05)$ than those of the slow-growers at Cga02 locus.

At all the loci except at $\mathrm{Cga03}, \mathrm{Cga} 05$ and $\mathrm{Cga06}$ loci, the single locus observed heterozygosity (ho) were higher, though non-significantly $(\mathrm{p}>0.05)$ in the fast- than in the slow-growing strains of adult $C$. gariepinus. The fast-growing strains of the fish also had higher single locus expected heterozygosity (he) than the slow-growing strains. The only locus where the slow-growers had higher he value than the fast-growing strains was Cga03. Analysis further revealed that it was only at $\mathrm{Cga02}$ that the recorded higher he values was significantly higher $(\mathrm{p}<0.05)$ in the fast-growers than in the slow-growing strains. Analysis of the fixation index (F) showed that the slow-growing strains of adult $C$. gariepinus had higher values (non-significantly different at $\mathrm{p}>0.05$ ) than the fast-growing strains. The exceptions occurred at loci Cga05 and Cga06 where the fast-growers had higher $\mathbf{F}$ value than the slowgrowers. 
Table 5. Genetic variability estimates using microsatellite allelic data of the fast- and slow-growing C. gariepinus strains based on each microsatellite locus. (Standard error in parentheses)

\begin{tabular}{|c|c|c|c|c|c|c|c|c|c|c|c|c|c|c|}
\hline \multicolumn{2}{|c|}{$\begin{array}{l}\text { Genetic } \\
\text { Indices }\end{array}$} & \multicolumn{12}{|c|}{ Primers (Loci) } & \\
\hline & \multicolumn{2}{|c|}{ Cga01 } & \multicolumn{2}{|c|}{ Cga02 } & \multicolumn{2}{|c|}{ Cga03 } & \multicolumn{2}{|c|}{ Cga05 } & \multicolumn{2}{|c|}{ Cga06 } & \multicolumn{2}{|l|}{ Cga09 } & Cga10 & \\
\hline & $\mathbf{F}$ & $\mathbf{S}$ & $\mathbf{F}$ & $\mathbf{S}$ & $\mathbf{F}$ & $\mathbf{S}$ & $\mathbf{F}$ & $\mathbf{S}$ & $\mathbf{F}$ & $\mathbf{S}$ & $\mathbf{F}$ & $\mathbf{S}$ & $\mathbf{F}$ & $\mathbf{S}$ \\
\hline $\mathbf{N a}$ & $\begin{array}{l}5.000 \\
(0.41)\end{array}$ & $\begin{array}{l}4.250 \\
(0.479)\end{array}$ & $\begin{array}{l}6.250 * \\
(0.479)\end{array}$ & $\begin{array}{c}4.250 \\
(0.250)\end{array}$ & $\begin{array}{c}5.750 \\
(0.854)\end{array}$ & $\begin{array}{l}6.750 \\
(0.946)\end{array}$ & $\begin{array}{c}4.250 \\
(0.479)\end{array}$ & $\begin{array}{l}4.250 \\
(0.25)\end{array}$ & $\begin{array}{l}5.000 \\
(1.080)\end{array}$ & $\begin{array}{l}5.250 \\
(0.75)\end{array}$ & $\begin{array}{r}6.250 \\
(1.031)\end{array}$ & $\begin{array}{l}5.500 \\
(0.957)\end{array}$ & $\begin{array}{c}6.000 \\
(1.080)\end{array}$ & $\begin{array}{l}4.750 \\
(0.479)\end{array}$ \\
\hline $\mathrm{Ne}$ & $\begin{array}{l}4.048 \\
(0.621)\end{array}$ & $\begin{array}{l}3.557 \\
(0.369)\end{array}$ & $\begin{array}{c}5.591 * \\
(0.256)\end{array}$ & $\begin{array}{l}3.763 \\
(0.441)\end{array}$ & $\begin{array}{l}4.517 \\
(0.898)\end{array}$ & $\begin{array}{l}6.134 \\
(0.742)\end{array}$ & $\begin{array}{l}3.974 \\
(0.498)\end{array}$ & $\begin{array}{c}3.482 \\
(0.192)\end{array}$ & $\begin{array}{l}4.331 \\
(0.964)\end{array}$ & $\begin{array}{l}3.972 \\
(0.891)\end{array}$ & $\begin{array}{l}5.377 \\
(0.808)\end{array}$ & $\begin{array}{l}4.661 \\
(0.847)\end{array}$ & $\begin{array}{l}5.327 \\
(1.094)\end{array}$ & $\begin{array}{l}3.729 \\
(0.180)\end{array}$ \\
\hline I & $\begin{array}{l}1.472 \\
(0.115)\end{array}$ & $\begin{array}{l}1.328 \\
(0.107)\end{array}$ & $\begin{array}{l}1.770^{*} \\
(0.061)\end{array}$ & $\begin{array}{c}1.372 \\
(0.084)\end{array}$ & $\begin{array}{l}1.585 \\
(0.159)\end{array}$ & $\begin{array}{c}1.831 \\
(0.152)\end{array}$ & $\begin{array}{c}1.388 \\
(0.126)\end{array}$ & $\begin{array}{c}1.339 \\
(0.051)\end{array}$ & $\begin{array}{l}1.468 \\
(0.205)\end{array}$ & $\begin{array}{c}1.456 \\
(0.186)\end{array}$ & $\begin{array}{l}1.722 \\
(0.167)\end{array}$ & $\begin{array}{l}1.575 \\
(0.165)\end{array}$ & $\begin{array}{l}1.679 \\
(0.183)\end{array}$ & $\begin{array}{l}1.423 \\
(0.074)\end{array}$ \\
\hline ho & $\begin{array}{l}0.263 \\
(0.047)\end{array}$ & $\begin{array}{l}0.200 \\
(0.082)\end{array}$ & $\begin{array}{l}0.300 \\
(0.129)\end{array}$ & $\begin{array}{l}0.063 \\
(0.063)\end{array}$ & $\begin{array}{l}0.438 \\
(0.075)\end{array}$ & $\begin{array}{l}0.450 \\
(0.150)\end{array}$ & $\begin{array}{l}0.050 \\
(0.05)\end{array}$ & $\begin{array}{r}0.100 \\
(0.058)\end{array}$ & $\begin{array}{r}0.263 \\
(0.125)\end{array}$ & $\begin{array}{c}0.438 \\
(0.140)\end{array}$ & $\begin{array}{c}0.400 \\
(0.123)\end{array}$ & $\begin{array}{c}0.300 \\
(0.129)\end{array}$ & $\begin{array}{c}0.300 \\
(0.173)\end{array}$ & $\begin{array}{c}0.250 \\
(0.096)\end{array}$ \\
\hline he & $\begin{array}{c}0.735 \\
(0.039)\end{array}$ & $\begin{array}{c}0.710 \\
(0.029)\end{array}$ & $\begin{array}{c}0.820 * \\
(0.008)\end{array}$ & $\begin{array}{c}0.724 \\
(0.029)\end{array}$ & $\begin{array}{c}0.757 \\
(0.037)\end{array}$ & $\begin{array}{l}0.828 \\
(0.026)\end{array}$ & $\begin{array}{c}0.735 \\
(0.036)\end{array}$ & $\begin{array}{c}0.710 \\
(0.017)\end{array}$ & $\begin{array}{c}0.740 \\
(0.045)\end{array}$ & $\begin{array}{c}0.711 \\
(0.058)\end{array}$ & $\begin{array}{l}0.800 \\
(0.032)\end{array}$ & $\begin{array}{l}0.768 \\
(0.034)\end{array}$ & $\begin{array}{c}0.790 \\
(0.037)\end{array}$ & $\begin{array}{c}0.73 \\
(0.013)\end{array}$ \\
\hline $\mathbf{F}$ & $\begin{array}{l}0.636 \\
(0.077)\end{array}$ & $\begin{array}{c}0.726 \\
(0.114)\end{array}$ & $\begin{array}{l}0.637 \\
(0.157)\end{array}$ & $\begin{array}{l}0.905 \\
(0.095)\end{array}$ & $\begin{array}{l}0.425 \\
(0.088)\end{array}$ & $\begin{array}{l}0.473 \\
(0.176)\end{array}$ & $\begin{array}{l}0.936 \\
(0.064)\end{array}$ & $\begin{array}{l}0.857 \\
(0.083)\end{array}$ & $\begin{array}{c}0.671 \\
(0.144)\end{array}$ & $\begin{array}{l}0.419 \\
(0.150)\end{array}$ & $\begin{array}{c}0.524 \\
(0.214)\end{array}$ & $\begin{array}{l}0.623 \\
(0.152)\end{array}$ & $\begin{array}{l}0.644 \\
(0.194)\end{array}$ & $\begin{array}{l}0.662 \\
(0.127)\end{array}$ \\
\hline
\end{tabular}


In total, 138 different alleles with 224 occurrences were observed (Fig. 2) in the entire sampled populations. Higher variability of 36,37 and 40 allelic numbers were shown by microsatellite loci Cga02, Cga03 and Cga09, respectively.

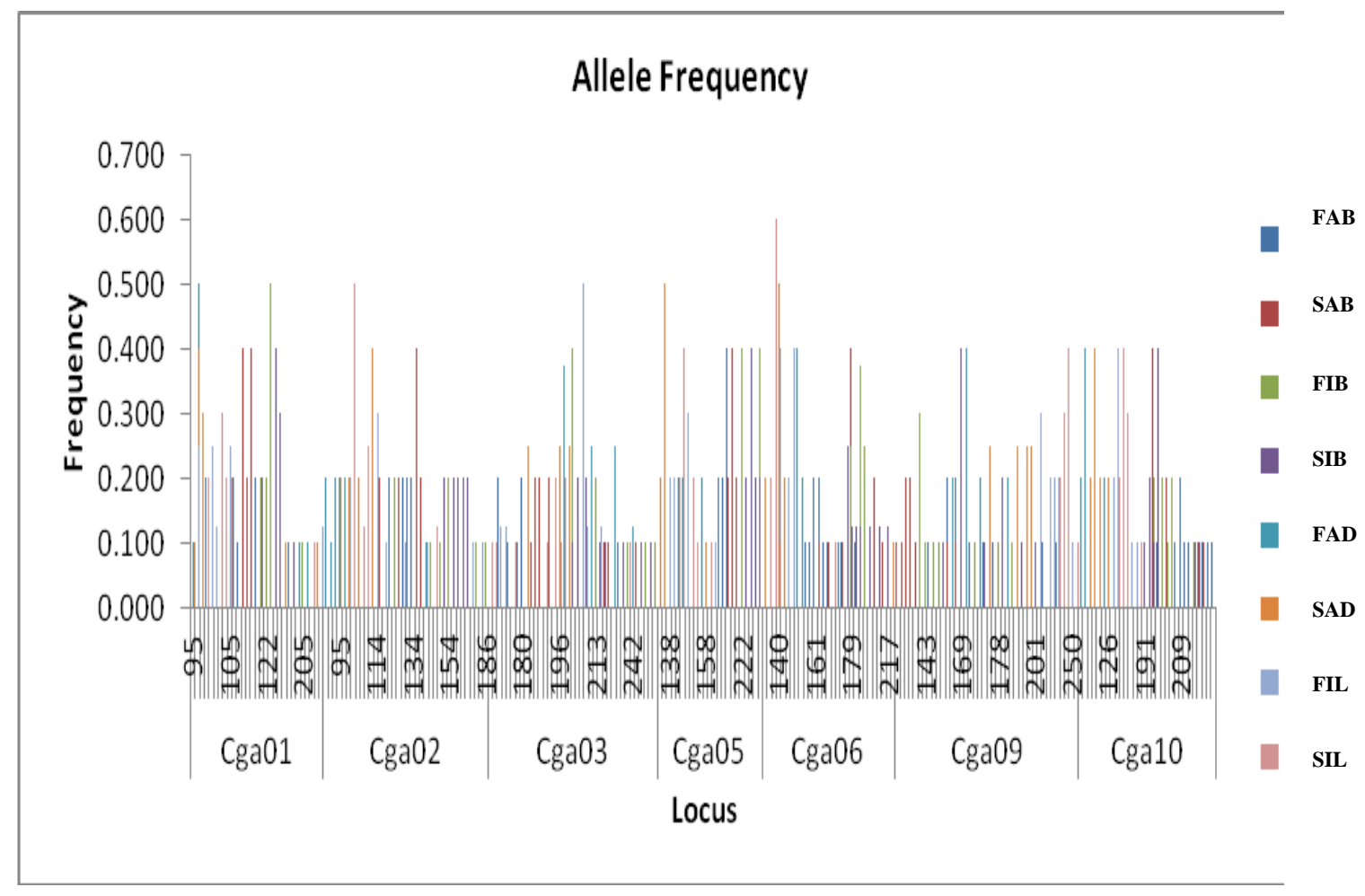

Fig. 2. Allele frequencies by population over loci

The distribution of genetic diversity in the studied populations (Fig. 3) revealed that 63 and $29 \%$ of the total variation existed among and within individuals, respectively; $5 \%$ among regions and $3 \%$ among populations.

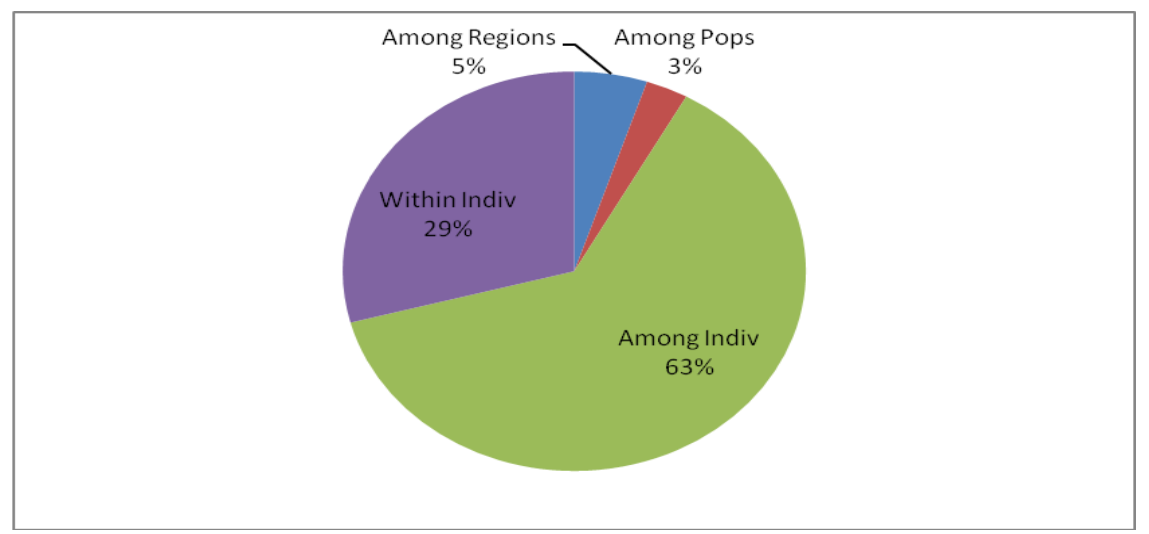

Fig. 3. Percentages of Molecular Variance: Input as allelic distance matrix for F-statistics analysis 
Analysis by Chi-square tests (Table 6) across all loci and populations revealed that not all the seven loci conformed to Hardy-Weinberg equilibrium in each population.

Table 6. Probability values for Hardy-Weinberg equilibrium obtained from Chi-Square tests

\begin{tabular}{llllllll}
\hline Population & \multicolumn{7}{c}{ Loci } \\
\cline { 2 - 8 } & \multicolumn{1}{c}{ Cga01 } & Cga02 & Cga03 & Cga05 & Cga06 & Cga09 & Cga10 \\
\hline Slow-growers & & & & & & & \\
SAB & $0.019 *$ & $0.020^{*}$ & 0.247 & $0.020^{*}$ & 0.172 & 0.170 & 0.132 \\
SIB & 0.103 & $0.029 *$ & 0.170 & $0.020^{*}$ & 0.293 & $0.050^{*}$ & $0.050^{*}$ \\
SAD & 0.113 & $0.020^{*}$ & 0.062 & 0.116 & 0.116 & 0.062 & $0.020^{*}$ \\
SIL & 0.113 & 0.062 & 0.170 & $0.029 *$ & $0.020^{*}$ & 0.103 & 0.103 \\
Fast-growers & & & & & & & \\
FAB & $0.050^{*}$ & $0.029 *$ & 0.170 & $0.020^{*}$ & 0.17 & 0.17 & 0.297 \\
FIB & 0.116 & 0.092 & $0.050 *$ & $0.019 *$ & 0.207 & 0.337 & $0.050^{*}$ \\
FAD & 0.125 & $0.050^{*}$ & 0.207 & $0.029 *$ & $0.029 *$ & $0.020 *$ & $0.020^{*}$ \\
FIL & 0.100 & 0.224 & 0.100 & 0.113 & $0.019 *$ & 0.113 & $0.029 *$ \\
\hline
\end{tabular}

* significantly different at $\mathrm{p}<0.05$.

$\mathrm{SAB}=$ Slow-growers Abeokuta, $\mathrm{SIB}=$ Slow-growers Ibadan, $\mathrm{SAD}=$ Slow-growers Ado-Ekiti, SIL= Slowgrowers Ile-Ife. FAB=Fast- growers Abeokuta, FIB= Fast-growers Ibadan, FAD= Fast-growers Ado-Ekiti, FIL $=$ Fast-growers Ile-Ife.

\section{DISCUSSION}

Fast-growing $C$. gariepinus strains especially those from Abeokuta location were more heterozygous in most loci probed than the slow-growing strains, however, the slowgrowing $C$. gariepinus strains exhibited higher homozygosity than the fast-growers. The result obtained probably confirmed that admixture of stocks might be routinely practised more frequently in the Abeokuta fish farm compared to the selected fish farms. The results obtained could also suggest that heterozygosity might have a positive effect on growth.

Genetic variability estimates for each growth group of $C$. gariepinus across the seven (7) microsatellite loci showed polymorphism in all the loci assayed. Agbebi $\boldsymbol{e t}$ al., (2013) similarly reported polymorphism of all loci (Cga01, Cga02, Cga03, and Cga05) assayed in the strains of clariid species. Fast-growers from the Abeokuta location was found to have the highest values for all the genetic indices measured across all loci while the slow-growing strain from Ado-Ekiti exhibited the lowest values across all loci except for the fixation index. Without associating growth values of these sub-populations with 
the genetic indices, significant differences were observed in number of alleles $(\mathrm{Na})$ between fast-growing strain from Abeokuta and Ado-Ekiti, between the fast-growers from Abeokuta and Ile-Ife on one hand and between the fast-growing strain from Abeokuta and the slow-growing strains from Ado-Ekiti and Ile-Ife respectively. A deviating trend was also recorded for number of effective alleles (Ne). Significant differences were recorded between the fast-growing strain from Abeokuta compared with fast-growers from Ibadan, Ado-Ekiti and Ile-Ife. Significant Ne values were also recorded between the fast-growers from Abeokuta, when compared with those of the slow-growing strains from Abeokuta, Ado-Ekiti and Ile-Ife respectively. The results were probably suggestive of the good quality of fast-growing strain especially the growth group, collected from the Abeokuta location. Pujolar et al. (2005), studying the growth and heterozygosity of European eel, Anguilla anguilla, observed that some slow-growing eel population presented higher observed heterozygosity at some specific loci, but generally fast-growing eels had the higher observed heterozygosity $(\mathrm{Ho}=0.726 \pm 0.275)$ when compared to the slow-growing eel $(\mathrm{Ho}=0.711 \pm 0.253)$. Likewise, comparisons between fast- and slow-growing strain of adult $C$. gariepinus from different locations also identified statistical significant differences $(\mathrm{p}<0.05)$ in number of alleles, number of effective alleles, Shannon's information index and single locus expected heterozygosity only at $\mathrm{Cga02}$.

With the exception of fast- and slow-growing strains from Ibadan, the individual heterozygosity was observed to be higher in all fast-growing $C$. gariepinus strains than those obtained in the corresponding slow-growing strain from the same location. This could be attributed to the higher number of heterozygote loci (in the fast-growers) used in calculating individual heterozygosity. This same trend was observed in the comparison of the fast- and slow- growing strains of $C$. gariepinus from the same location using other genetic indices. The only exception recorded was for fixation indices where the higher genetic variability recorded in the slow-growers from Ibadan could not be explained.

Similarly, the highest recorded value (0.834) for fixation index (F) / inbreeding coefficient/ heterozygosity deficit was observed in the slow-growing strain from AdoEkiti while the least value (0.536) was recorded in the fast-growing strain from Abeokuta across all loci analysed. Generally, fast-growing C. gariepinus strains showed smaller value of inbreeding coefficient than the slow-growing ones. The result corroborated of Ojango et al. (2011) observation that a large value of inbreeding coefficient typifies the existence of a small number of heterozygote genotypes and an excess of homozygote genotypes, while a small value denotes the occurrence of heterozygote genotypes at a higher proportion than the homozygote genotypes. According to Pierce (2012), inbreeding coefficients can range from 0 to 1 . A value of 0 implies that mating in a large population is random; a value of 1 infers that all alleles are identical by descent. 
In addition, a high diversity is not only vital for the enhancement of stocks, but will also increase the ability of the population to resist diseases and allow adaptation to possible environmental changes (Gamfeldt and Kallstrom, 2007). This study has identified fast-growing $C$. gariepinus as strains with higher genetic variability than the slow-growing strains. Strain identification is complicated, since fixed, strain-specific markers are not usually available for strains within a species. The amount of genetic variation among strains which might be limited may require DNA markers and techniques with higher resolution than traditional markers such as allozymes or RAPDs. Allele frequencies for each microsatellite locus which were evaluated for each strain and those microsatellites that have highly differential allele frequencies among strains are used for strain identification (Liu and Cordes, 2004). Some strains of fish species have been identified through this approach (David et al., 2001; Mickett et al., 2003).

The non-conformities to Hardy-Weinberg equilibrium observed probably suggested that at these loci, evolution may be occurring in some of the growth groups. An implication of the Hardy-Weinberg law for the genetic structure of a population is that a population cannot evolve if it meets the Hardy-Weinberg assumptions, because evolution involves change in the allelic frequencies of a population (Pierce, 2012). Deviation from HWE was observed mostly at Cga05. This is similar to Galbusera et al., (1996) who reported significant deviations at loci $\mathrm{Cga05}$ and $\mathrm{Cga09}$ in the characterization of $C$. gariepinus.

\section{CONCLUSION}

This study has identified fast-growth catfish as a strain with larger genetic variability than slow-growth strain. Estimates of $\mathrm{Na}$, Ne, I, He and H-indiv. could be used in future breeding studies as markers of relative growth potential, and these can help in conservation of biodiversity of $C$. gariepinus. Also, $\mathrm{Cga} 02$ has been discovered as the specific locus on which significance levels were consistently expressed thus, it should be explored in future studies in larger populations of $C$. gariepinus since it showed promising higher potential for improvement of growth performance in the fish. In spite of these results, studies on genetic-diversity-fitness correlations for culturable species with shooter-phenomenon are recommended.

\section{REFERENCES}

Adewumi, A. A. and Ola-Oladimeji, F. A. (2016). Performance characteristics and feed utilization of African Catfish (Clarias gariepinus) fed varying inclusion levels of fermented mulberry leaf. DRJAFS, 4 (5): 87-93.

Agbebi, O. T.; Ilaboya, D. E. and Adebambo, A. O. (2013). Preliminary characterization of genetic strains in clariid species, Clarias gariepinus and 
Heterobranchus bidorsalis microsatellite markers. Afr. J. Biotechnol, 12 (4): 364369.

Aluko, P.O. and Awopetu, J.I. (1995). Karyotype of two cichlid fishes: Oreochromis niloticus, Sarotherodon galilaeus and their hybrids- O. niloticus x $S$. galilaeus. Niger. J. Genet., 10: 87-91.

Awodiran, M.O.; Aluko, P.O. and Adegoke, J.A. (2000). Morphometric characteristics, survival and growth of hybrids between Clarias anguillaris (Linnaeus 1758), and Heterobranchus longifilis (Valenciennes 1840). Niger. J. Genet., 15: 46-53.

Awodiran, M.O. and Afolabi, O. (2018). Genetic Diversity in Cultured and Wild Population of Clarias gariepinus (Burchell, 1822) in Nigeria Using Random Amplified Polymorphic DNA (RAPD) and Microsatellite DNA. Fish. Aquac. J., 9: 247. doi:10.4172/2150-3508.1000247

David, L.; Rajasekaran, P.; Fang, J.; Hillel, J. and Lavi, U. (2001). Polymorphism in ornamental and common carp strains (Cyprinus carpio L.) as revealed by AFLP analysis and a new set of microsatellite markers. Mol. Genet. Genom., 266: 353362.

Dunham, R. A. (2011). Aquaculture and Fisheries Biotechnology: Genetic Approaches, second ed. CAB International, Wallingford, UK. 495pp.

El-Mogy, M.; Simkin, M. and Haj-Ahmad Y. (2016). Comparative study of DNA isolated from increasing volumes of blood using Norgen's blood genomic DNA isolation kit versus Qiagen's QIAamp DNA blood mini kit. Norgen Biotechnology Corporation: Application Note 59 Blood DNA Preparation, Norgen Biotek Corp., Canada. pp. 1-3.

Galbusera, P.; Volckaert, F.A.; Hellemans, B. and Ollevier, F. (1996). Isolation and characterization of microsatellite markers in the African catfish Clarias gariepinus (Burchell 1822). Mol. Ecol., 5: 703-705.

Gamfeldt, L. and Kallstrom, B. (2007). Increasing intraspecific diversity increases predictability in population survival in the face of perturbations. Oikos, 116: 700705 .

Ikpeme, E.V.; Udensi, O.U.; Ekaluo, U.B.; Kooffreh, M.E.; Okolo, C.M.; Ekpo, P.B. and Ogbonna, N.C. (2015). Unveiling the genetic diversity in Clarias gariepinus (Burchell 1822) using Random Amplified Polymorphic DNA (RAPD) fingerprinting technique. Asian J. Anim. Sci., 9: 187-197.

Karsi, A.; Patterson, A.; Feng, J. and Liu, Z.J. (2002). Translational machinery of channel catfish: I. A transcriptomic approach to the analysis of $3240 \mathrm{~S}$ ribosomal protein genes and their expression. Gene, 291: 177-186.

Li, Y. C.; Korol, A. B.; Fahima, T.; Beiles, A. and Nevo E. (2002). Microsatellites: genomic distribution, putative functions and mutational mechanisms: a review. Mol. Ecol., 11: 2453-2465. 
Liu, Z.J. and Cordes, J.F. (2004). DNA marker technologies and their applications in aquaculture genetics. Aquac., 238 (1-4): 1-37.

Majolagbe, F.A.; Awopetu, J.I. and Omitogun, O.G. (2011). Cytogenetical study of Clarias gariepinus (Burchell 1822) and Heterobranchus bidorsalis (Geoffroy SaintHilaire 1809) and their reciprocal hybrids. ADSU J. Sci. Res., 1 (1): 32-38.

Mickett, K.; Morton, C.; Feng, J., Li, P.; Simmons, M.; Dunham, R.A.; Cao, D. and Liu, Z.J. (2003). Assessing genetic diversity of domestic populations of channel catfish (Ictalurus punctatus) in Alabama using AFLP markers. Aquac., 228: 91-105.

Olaleye, V.F. (2005). A review of reproduction and gamete management in the African catfish Clarias gariepinus (Burchell). Ife J. Sci., 7 (1): 63-70.

Ola-Oladimeji, F.A.; Awodiran, M.O.; Olaleye, V.F. and Awopetu, J.I. (2020). Genetic Characterization Based on RAPD-PCR in Cultured Strains of Clarias gariepinus (Siluriformes: Clariidae). Genet. Aquat. Org., 4 (1): 81-88. http://doi.org/10.4194/2459-1831-v4_2_03

Ojango, J.M.; Mpofu, N.; Marshall, K. and Andersson-Eklund, L. (2011). Quantitative methods to improve the understanding and utilisation of animal genetic resources In: "Animal Genetics Training Resource, Version 3, 2011." Ojango, J.M., Malmfors, B. \& Okeyo, A.M. (Eds). International Livestock Research Institute, Nairobi, Kenya, and Swedish University of Agricultural Sciences, Uppsala, Sweden. 4: 1-39.

Olaleye, V.F. (2005). A review of reproduction and gamete management in the African catfish Clarias gariepinus (Burchell). Ife J. Sci., 7 (1): 63-70.

Olaniyi, W. A. and Omitogun, O. G. (2012). Induction of diploid gynogeneic larvae of African catfish, Clarias gariepinus Burchell 1822. Ife J. Agric., 25: 73-82.

Olaniyi, W. A. and Omitogun, O. G. (2014). Embryonic and larval developmental stages of African giant Catfish Heterobranchus bidorsalis (Geoffroy Saint Hilaire 1809) (Teleostei, Clariidae). SpringerPlus, 3: 677.

Onura C.N.; Van den Broeck, W.; Nevejan, N.; Muendo, P. and Van Stappen, G. (2018). Growth performance and intestinal morphology of African catfish (Clarias gariepinus, Burchell 1822) larvae fed on live and dry feeds. $\quad$ Aquac., 489 (20): 7079.

Peakall, R. and Smouse, P. E. (2012). GenAlEx 6.5: Genetic analysis in Excel. Population genetic software for teaching and research - an update. Bioinformatics, 28: 2537-2539.

Pierce, B.A. (2012). Genetics; A Conceptual Approach, fourth ed. W. H. Freeman and Company, New York, 745 pp.

Popoola, O.M.; Fasakin, E.A. and Awopetu, J.I. (2014). Genetic variability in cultured and wild populations of Clarias gariepinus (Osteichthys: Clariidae) using Random Amplified Polymorphic DNA (RAPD) marker. Croat. J. Fish., 72: 5-11.

Pujolar, J. M.; Maes, G. E.; Vancoillie, C. and Volckaert, F.A.M. (2005). Growth rate correlates to individual heterozygosity in the European eel, Anguilla anguilla L. Evol., 59 (1): 189-199. 